\title{
THE LIMITS OF WORKING WITH CHILDREN CARDS IN PROTECTING CHILDREN
}

William Budiselik, Frances Crawford and Joan Squelch

Curtin University of Technology Western Australia 


\section{Abstract}

In 2006 Western Australia (WA) proclaimed legislation which introduced a system to check the criminal records and issue permits to those who wish to work with children. In 2007 the legislation was described by the Minister responsible as a 'powerful system that would prevent harm to children'. This paper explores that system and identifies limits to its effectiveness. The paper concludes unless the system's limits are fully appreciated there is a possibility of a paradoxical outcome and children's lives will be less safe. It also raises the question of whether in the area of record checking a national approach is not more preferable than each state and territory developing its own system. 
THE LIMITS OF WORKING WITH CHILDREN CARDS IN PROTECTING

\section{CHILDREN}

\section{Introduction}

Sick kids molested at camp, court told. A WA man charged with molesting four seriously ill children while supervising a holiday camp for them was convicted of similar offences in the United States 11 years ago ("Sick kids," 2004).

Confidential government reports reveal social workers' inadequate assessments led to children dying (Gibson, 2007).

Such headlines fuel the anxieties of children's carers and pressure politicians to assure constituents that strategies certain to protect children from abuse are at hand. Though it is important for children and reassuring for caregivers that abuse dangers are minimised, it is also important that the community is not misled about the effectiveness of strategies to reduce abuse dangers, and that desperately needed childwelfare resources are not consumed in the pursuit of the unachievable.

From 1996/97 to 2006/2007 the Australian Institute of Health and Welfare reported nearly 1.8 million notifications of child abuse were made across Australia (Australian Institute of Health and Welfare (AIHW), 1999, 2000, 2007, p. 21, 2008). While the number of notifications is staggering it is salutary to note "child maltreatment is under-reported due to assignment of responsibility solely to parents, resulting in the omission of many cases of extra-familial abuse" (Bromfield and Higgins, 2004, p. 28).

Notwithstanding that the quantum of organisation-located abuse is unknown, Western Australia (WA) is investing heavily in checking the criminal records of 
people working with or wishing to work with children. However, there is a general consensus that criminal record screening by itself is not an effective means of preventing organisation-located abuse. Those who provide child protection consultancy services to organisations consider criminal record screening as one aspect of comprehensive recruitment (Childwise, 2008, p. 9; see also Bichard, 2004, I 3.83) and comprehensive recruitment is seen as one "component of a multi-faceted system required to safeguard children and young people" (Sylvan and Franco, 2008, p. 9). Irenyi, Bromfield, Beyer and Higgins (2006, p.17) conclude from their review that "screening is an important means of keeping known perpetrators from infiltrating child focussed organisations" and that it is "not without its limitations".

Gill (2007, pp. $46-48)$ is critical of the United Kingdom's workforce vetting model on several counts, arguing that such a system, "if taken too far", may ultimately compromise "the very bonds which make communities welcoming, safe places for children" and questioning its cost, including opportunity costs. With respect to the latter he says because of the threat of fines for non-compliance "many agencies will therefore focus solely on carrying out checks at the expense of other measures, such as training and awareness-raising, which could be more effective in protecting children from abuse".

WA's lawmakers have provided a legislative foundation for an approach to preventing people with certain criminal records from working with children in organisations. However from the perspective of protecting children relevant questions to be considered include: will children be safer as a result of the legislation; and, does the cost of the system represent a good use of scarce resources? This paper argues that there is no quick-fix to be found to the organisation-located abuse of children in the WA Working with Children card. 
The West Australian Working with Children Check

The Working with Children (Criminal Record Checking) 2004 Act (WA) (the Act) was proclaimed on 1 February 2006. By 2010 all employees and volunteers in child related work, as specified in the Act, will be required to possess a "working with children check" card. The Act is administered by the WA Department for Child Protection (DCP) and is aimed at protecting children by screening those seeking to work and working with children by examining their criminal record. In February 2007 the Minister for DCP told WA's Parliament:

This is a powerful system to prevent harm to children. Introducing these checks will prohibit people who pose a risk from working with many thousands of children. Prior to this Act, some who are dangerous to children would not have been identified, especially self-employed people or those who do not have convictions but have faced charges. (Templeman, 2007)

The legislation promised an additional strategy to protect children. However, State Administrative Tribunal (the Tribunal) decisions ( $C$ and Chief Executive Officer, 2007; Department for Community Development, 2007; D and Department for Community Development, 2007; S and Chief Executive Officer, Department for Community Development, 2007) raise questions about the legislation's effectiveness and whether the State is capable of preventing people from "working with children", even when they have a criminal record for offences against children.

\section{Background to the legislation}

The 1994 - 1997 Wood Royal Commission into the New South Wales Police Force inquired extensively into paedophilia and led to legislatively sanctioned criminal record checking as a child safety initiative in Australia. Wood recommended a Children's Commission in New South Wales and proposed it would have 
statutory authority to issue an unacceptable risk certificate automatically in cases in which a person is:

- Convicted of a criminal charge involving child sexual abuse; or

- Found guilty of a breach of discipline involving child sexual abuse; and

- Otherwise, where satisfied, after due inquiry, that the person poses an unacceptable risk as outlined. (Wood, 1997, vol 5 p. 270)

In 1996, in the context of the Royal Commission, the state and territory Community Services Ministers agreed to implement safety screening of persons employed in a paid or voluntary capacity in services for children. WA joins New South Wales (1998), Queensland (2000) and Victoria (2005) as the Australian jurisdictions with criminal record checking legislation. In characteristic Australian fashion, each has different procedures and requirements.

The purpose of the Act is to provide for procedures for checking criminal records of people who work with children and to prevent people who have been charged or convicted of certain offences from carrying out child-related work. The legislation is intended to

- deter those with criminal records from applying for positions to work with children if their record indicated they might harm children;

- prevent those with such criminal records from getting into positions of trust in paid and unpaid employment;

- establish consistent standards for criminal record screening; and,

- raise community awareness that keeping children safe is a whole of community responsibility (Department for Child Protection, 2005). 
The legislation

While it is not within the scope of this article to provide a detailed analysis of the legislation some relevant features are canvassed. In the Act a criminal record refers to a conviction or charge for an offence in WA or another jurisdiction. The Act classifies offences into Class 1 (listed in Schedule 1) and which relate primarily to serious sexual offences against children and Class 2 offences (Schedule 2) which covers 54 criminal offences. Class 2 offences include offences against children, for example indecently recording a child under 13, sexual offences against a child of or over 13 and under 16 as well as offences such as murder and manslaughter.

In s 6 "child-related work" is defined broadly, encompassing activities which include people working in child-care, child-minding, education, religious organisations, clubs and associations, children's entertainment, overnight camps and school crossing services. Child-related employment refers to individuals working under an employment contract, on a voluntary basis or in a religious organisation.

A person may apply to the Chief Executive Officer (CEO) of DCP for a Working with Children card. The card, which is in a driver's licence style, including photograph, is valid for 3 years and permits a person to carry out child-related work. A card is issued automatically when the CEO is unaware of any conviction or charge against an applicant. If the CEO is aware of a non-conviction charge for a Class 1 or Class 2 offence, a card will be issued unless there are particular circumstances which require it not to be issued. If the CEO is aware of a conviction for an offence other than those offences listed in the Schedules a card will be issued unless there are particular circumstances which require it not to be issued. A card will not be issued if the CEO is aware the applicant has a conviction for a Class 1 offence from when the applicant was a child or a conviction for a Class 2 offence or has a charge pending for 
a Class 1 or Class 2 offence, unless there are exceptional circumstances which permit a card to be issued. A card will not be issued if the applicant has been convicted of a Class 1 offence, other than when the applicant was a child. If a card is denied a person is prohibited from working with children and a negative notice is issued, which remains in force until it is withdrawn.

While the Act does not define particular or exceptional circumstances, s12(8) provides that the CEO should consider: the best interests of the child; when the offence was committed; the age of the applicant; the nature of the offence; any information provided by the applicant; and, anything else the CEO reasonably considers to be relevant to the decision.

\section{Decided cases}

To 30 June 2008 DCP had issued 128,147 cards and 46 negative notices. Of the individuals issued with a negative notice, eight appealed the DCP's decision to the Tribunal (Department for Child Protection, 2008). Of these eight cases, three have now been decided. Subsection 105(2) of the State Administrative Tribunal Act 2004 (WA) allows for appeals of the Tribunal's decisions to a court only on a question of law. Two of the decided cases involved appeals to the Western Australian Supreme Court of Appeal (the Court). These three cases are now discussed in more detail.

The case of ' $C$ '

In April 2006 'C', a T-Ball coach, applied for a card. 'C'”'s record showed a non-conviction charge which meant the CEO may issue a card unless there are particular circumstances which require a card not be issued. The CEO rejected 'C'"s application and refused to issue a card (issued a negative notice). ' $\mathrm{C}$ ' had been convicted in 1999 in the District Court of WA of offences against a 6 year old girl, 
' $A$ ', when he was employed as a 'nanny/babysitter' to look after ' $A$ ' and her sister and brother. In 1997 'C', then aged 34 years, cared for the children overnight at his accommodation. 'A', dressed in a tee-shirt and no knickers slept in 'C''s bed. 'C' was wearing boxer shorts. 'A' alleged ' $C$ ' kissed her on two occasions on the mouth and in doing so put his tongue in her mouth. 'A'"s younger sister also made allegations of criminal behaviour about ' $\mathrm{C}$ ', however, these allegations did not proceed in a subsequent indictment. In 1999 the Court of Criminal Appeal set aside the convictions and the Director Public Prosecutions elected not to proceed with a re-trial because it was not in the public interest ( $C$ and Chief Executive Officer, Department for Community Development, 2007, II 55).

The Tribunal placed much weight on whether ' $\mathrm{C}$ ' put his tongue in A's mouth. The Tribunal concluded while ' $\mathrm{C}$ ' kissed the girl on the mouth and arranged for her to sleep in his bed it could not be satisfied he had put his tongue in her mouth. The Tribunal described 'C"'s behaviour as "unacceptable" and "difficult to justify in any circumstances" (Ibid, \ 113). However, the Tribunal noted it "is bound to have regard to the facts that courts have always weighed the evidence of children with caution" (Ibid, II 79).

' $\mathrm{C}$ 's age at the time of the offence was considered and evaluated in the following terms "if the applicant were relatively young at the time, he or she may have outgrown a certain immaturity then they had and may possibly be considered, taking into account other factors, unlikely to engage in such conduct again ...maturity does not always sit comfortably on the shoulders of 34-year-olds" (Ibid, ๆ 101 - 102). The Tribunal set aside the CEO's decision and ordered ' $\mathrm{C}$ ' receive a card. 
In August 2007 the DCP sought from the Court a stay of the order made by the Tribunal pending the determination of an appeal of the Tribunal's decision. The Court dismissed this appeal because of a technical legal reason, it stated,

a stay cannot, however, be granted in that the status quo which existed before the Tribunal made its orders was disturbed by the appellant's action in issuing an assessment notice to the respondent instead of making application for a stay contemporaneously with the filing of the appeal notice. (Chief Executive Officer, Department for Child Protection-v-C, 2007. II 18)

In February 2008 the Court upheld DCP's appeal against the Tribunal's decision, lifted an order suppressing the person's name and remitted the case back to the Tribunal, differently constituted, for reconsideration (Chief Executive Officer, Department for Child Protection v Grindrod, 2008 II 119). On 9 December 2008, more than a year after a card was issued, the Tribunal affirmed DCP's original decision to issue a negative notice (Grindrod and Chief Executive Officer Department for Community Development, 2008). At the Tribunal's second hearing the character witnesses supporting the appellant were cross-examined. The Tribunal expressed its concern about the witnesses' denial of the possibility that Mr Grindrod had committed the acts of which he was accused and whether they fully appreciated of the extent of his admitted conduct (ibid, II 34). The Tribunal's reasons also included "there is no evidence Mr Grindrod now accepts that his admitted conduct was inappropriate ...We are not satisfied that he now possesses a greater maturity or insight than he had as a 34-year-old" (Ibid, II 44).

The case of ' $D$ '

' $\mathrm{D}$ ' had two convictions in 1980 for the indecent assault of his step daughter "then aged 5 or 6" (D and Department for Community Development, 2007, II 3) when 
he was 26 years of age. 'D' applied for a card in 2006 after he had worked for more than 10 years for the Salvation Army. The CEO rejected the application and 'D' appealed the decision to the Tribunal.

The Tribunal took the view that ' $\mathrm{D}$ 's convictions followed substance and alcohol abuse and that since 1991, when he became associated with the Salvation Army, he had turned his life around. In 1995 he was appointed to a position of responsibility in one of the Army's WA services. The Tribunal noted

The past 12 years of the applicant's life comprise a period of dedicated service to his community and his faith. The long period of his consistent and changed lifestyle suggests that any prospects of reverting to substance abuse or otherwise reigniting the "danger factors" that no longer form part of his lifestyle is (sic) minimal. If he were to relapse into a life of substance abuse and antisocial behaviour, it is unlikely he would maintain his position within the Salvation Army and thus continue the contact with children in relation to which the assessment notice is sought. (Ibid, II 60) In addition, in ' $\mathrm{D}$ ' 's case the Tribunal was influenced by a psychologist's evidence - "the applicant subjected himself to a psychological assessment ... the opinion of Dr ... that $\mathrm{D}$ represents a low risk of re-offending is relevant to the decision and I consider it to be an important factor in the assessment of the best interests of children in this case" (Ibid, II 64).

The Tribunal considered these were exceptional circumstances and that a card could be issued. DCP did not appeal the Tribunal's decision. 
The case of ' $S$ '

'S'’s convictions from 1977 and 1981 were not listed in Schedules 1 or 2 of the Act and the CEO used powers in s 12(5) to decide that in the particular circumstances of the case a card should not be issued.

The 1977 convictions were for offences of a sexual nature and in 1981 'S's victim was a seven year old girl. The police statement recorded ' $\mathrm{S}$ ' who was then 38 years old became "sexually aroused and placed his hand underneath her bedclothing and fondled the complainant's vagina...S readily admitted the offence and in explanation said he lost control because he was drinking and that he would seek medical treatment" (S and Chief Executive Officer, Department for Community Development, 2007, II 19).

The Tribunal's conclusion was "a period of 26 years has passed since the most recent conviction, and the applicant enjoyed strong support from those associated with his athletics club for his continued involvement in training young athletes. It concluded that, in the particular circumstances, a negative notice should not issue because it did not consider that children were likely to be at risk from continued contact with the applicant” (Ibid, \ 3). The Tribunal made a favourable judgment despite expressing "some level of concern at the refusal of S to acknowledge any wrongdoing in the past" (Ibid, - 42). It held the convictions against ' $S$ ' were old and that he had not proved himself to be a risk to children.

DCP unsuccessfully appealed the decision to the Court (Chief Executive Officer, Department for Child Protection-v-Scott, 2008). The majority of the Court dismissed the grounds for the appeal, which were about the way the Tribunal constructed its interpretation of sections of the Act, and consequently it did not consider the Tribunal's concern about S's failure to acknowledge wrongdoing in the 
past, which appeared ultimately to have been a relevant consideration in Grindrod's case.

What of the best interests of the child?

As already noted, one purpose of the Act is to prevent people with criminal records from working with children if the records indicate they might harm children. Moreover, the legislation and decisions emphasise the best interests of the children as being paramount. The Tribunal reasserted the pre-eminence of the child's best interests.

The paramount consideration means that, if having regard to the particular circumstances of the case there is a well-founded concern that the best interests of children might be put at risk if an assessment notice were to be issued, then a negative notice should be issued notwithstanding the adverse effect it may have on the applicant. ( $C$ and Chief Executive Officer, Department for Community Development, 2007, II 46)

However, "an assessment of the best interest of the child does not require a determination that there is no risk whatsoever of reoffending" ( $D$ and Department for Community Development, 2007, I[ 65). The Tribunal amplified it could not act on a concern, if it did not have a foundation in fact or probability.

However reference to the paramount consideration cannot turn a mere concern for which there is no proper foundation into a fact or a probability. For example, in this case the paramount consideration cannot be relied on to support a finding that in all probability the applicant did put his tongue into the young girl's mouth when he kissed her ( $C$ and Chief Executive Officer, Department for Community Development, 2007, II 126). 
From our perspective that a 34 year old ' $\mathrm{C}$ ' arranged for a 6 year old girl to sleep in his bed naked from the waist down, that he kissed her on her mouth and that both the girl and her sister alleged further misconduct indicate well-founded concerns. The initial Tribunal's conclusion that the behaviour was "unacceptable" and "difficult to justify" indicated it shared the concerns but concluded it could not act on them because they in themselves would not have resulted in a successful prosecution at law.

In 'D' 's case, his church employment played a significant role in the Tribunal's decision to uphold his appeal, because of the church's capacity and responsibility to moderate and provide a safe context for his behaviour. It is relevant to note in 2004 a federal government inquiry into past child abuse found "churches, religious orders and agencies have adopted varying approaches, usually from reticence to denial, towards accepting responsibility for conditions in institutions and acknowledging past abuse" (Australian Senate Community Affairs Committee, ch 7, p. 184).

\section{Discussion}

The political rhetoric associated with the legislation implies there is a "safe" organisational life for children, a life free of fear for parents. In the second reading speech the Minister concluded her speech:

This Government will not tolerate persons who prey on innocent children, and this legislation will put in place the tough measures that are needed to protect children from persons with criminal histories from seeking out workplaces in which there is access to children (McHale, 2004, p. 6945b-6949a). 
While checking a criminal record and issuing a working with children check cards is one strategy aimed at preventing child abuse, there are a number of limitations to the effectiveness of the card, in particular:

- Exemptions;

- Scrutiny of records from other jurisdictions;

- Not examining relevant non-criminal records of people who do not have a criminal record;

- Cost and duplication;

- The limited role for child protection expertise

\section{Exemptions}

The Act makes provision for a number of exemptions including: when a volunteer is under the age of 18 ; in most circumstances when a parent volunteers, provided their child participates in the activity; short term visitors to WA; and, employers of children. This section considers the first two listed exemptions.

With respect to volunteers who are youth a high proportion of child abuse, including sexual abuse, is perpetrated by other children. Australian and international estimates of sexual abuse of children by other children and youth range from $20 \%$ (Davis and Leitenberg as cited in James, 1996, p.3), 25 - 33\% (Green \& Masson, 2002, p. 150) and $40 \%$ and $39 \%$ for victims less than 6 years of age and 11 years of age (Snyder as cited in Oliver, 2007, p. 683). Children's Court records are checked when an adult is required to apply for a card. Yet volunteers under the age of 18 years do not require a card. Even if a card was required by volunteers under the age of 18 years 
few children would have records that warranted them being issued with negative notices, even if they have the propensity to offend. This encapsulates a fundamental dilemma inherent in criminal record screening. In her second reading speech the Minister assured the community "we will not tolerate paedophiles who have escaped conviction for various reasons working with our children" (McHale, 2004, p. 6945b 6949a). Arguably a more protective organisational environment will result if there is a realistic acceptance that inevitably a number of paedophiles work with children.

As far as parents are concerned the legislation appears incapable of responding to obviously dangerous situations. For example in the Perth suburbs "a 48-year-old man charged with assault after knocking unconscious his son's 13-year-old opponent at a weekend football match" ("Father faces ban," 2007) is able to volunteer at clubs or activities without a card, provided his son participates. In most circumstances it seems a person charged or convicted of any level of offence can, provided they are a parent and their child participates in the activity, work as a one of the volunteers among all the children involved.

\section{Scrutiny of records from other jurisdictions}

The State does not have the agreements in place with other countries or the means to check relevant overseas records, which is significant given the 2001 census showed $27 \%$ of the State's population were born overseas (Australian Bureau of Statistics, 2006). Additionally the State's checking unit is unable to obtain information from all other Australian states and territories about a person's criminal record. 
Not examining relevant non-criminal records of people who do not have criminal records

Many records relevant to whether a person is suitable to work with children are held by governments' agencies. For example, DCP's legislative mandate requires it to investigate allegations of child abuse and to act on them in the context of a child protection system. In each jurisdiction the courts' decisions about custody and access are made on the basis of probative evidence about abuse risk. In considering an appeal from the DCP about the Tribunal's decision to issue a card the Court referred to the High Court's test to decide whether to allow a parent custody or access to their child, expressed as "to achieve a proper balance, the test is best expressed by saying that a court will not grant custody or access to a parent if that custody or access would expose the child to an unacceptable risk of sexual abuse" $(M-v-M$ as cited in Chief Executive Officer, Department for Child Protection-v-Scott, 2008, ๆ 124).

It is considered by these authors to be inconsistent that information derived by child protection workers from a State sanctioned child abuse investigation, substantiated to the satisfaction of expert and appropriately delegated professional officers and used as the basis of removing a child from their parents or prosecuting a case in the Children's Court or determined in other courts cannot be used to assess a person's suitability for a card. Currently such information only comes into play if the person who applies for a card is one of a small percentage of applicants who has been charged or convicted of a relevant offence.

Information about persons believed responsible for child abuse, held in DCP's data bases, is assessed within DCP and might prevent a person being appointed as an employee of DCP, caring for children who are in the State's care or providing 
services to them, for example, as a tutor. This information is evaluated by the DCP and decisions made whether the person is charged with offences or not. DCP officers were not formally interviewed for this article. However, one senior DCP officer advised, off the record, of 2,000 departmentally substantiated cases of child abuse reviewed, less than 40 had resulted in criminal prosecution.

\section{Cost and duplication}

Many employers, including the DCP, require employees and volunteers to provide both a National Police Certificate and the State card. The National Police Certificate is obtained via the federal government police agency, Crimtrac, at a cost of $\$ 44.50$. The WA Working with Children check process scrutinises more of a person's record (i.e. charges and Children's Court record) than is made available when one applies for the National Police Certificate. However the State's process does not result in the employer being made aware of a person's criminal record. The National Police Certificate process results in a potential employee's offence history (less charges and Children's Court record) being made known to the employer.

While an accurate figure of the total cost of criminal record checking in WA, including the checks and the police certificates is not available, it is clearly significant. In 2007 there were twenty-seven staff employed in the DCP's working with children screening unit (Department for Child Protection, 2007, p. 59). Of course staffing is only part of the cost associated with this endeavour, the computation of the total cost requires not only all DCP's inputs, including funds provided to Crimtrac to access the national data base, but also those of other WA government departments delegated to perform the checks, the cost to individuals of both the WA card and the National Police Certificate and the administrative and personnel costs absorbed by organisations in ensuring people have the clearances and that they are re-applied for 
in accordance with the law and the organisation's policy. A total figure for WA alone might well be in the vicinity of $\$ 10$ million per annum.

Some individuals with roles in national children's organisations have to obtain cards from each of the states within which they work and also obtain a National Police Certificate. A question which must surely be raised is why a national approach is not possible to determine whether a person's known criminal record ought to preclude them from working with children anywhere in the country.

\section{The role of child protection expertise}

Prior to the Tribunal setting aside DCP's decisions the Minister's view of the DCP's decision making was set out in her second reading speech when she said "the screening unit will employ people with the child protection and legal expertise needed to make the complex decisions about whether a person's criminal history indicates likely harm of children" (McHale, 2004, p. 6945b - 6949a) and later in response to a parliamentary question when she said "the Working with Children check is made by a specialised unit which make assessment decisions based on a carefully devised assessment framework" (McHale, 2005, p. 8162b). The Minister's responses demonstrated a belief that child abuse prevention was possible, given carefully constructed actuarially orientated assessment frameworks. Eighteen months later when the subsequent responsible Minister was asked a question about the impact of the Tribunal's decisions she answered "bureaucrats should not be allowed to make arbitrary decisions that cannot be appealed. This makes the laws strong and fair. The Tribunal is required to reach what it considers to be the correct decision" (Ellery, 2007). 
The latter answer implied DCP's decisions were bureaucratic - achieved through the application of known rules. The Minister avoided implying there was an expertise involved in the decision making or that the decisions were made in part by child protection experts or involved the application of other than bureaucratic expertise. The discourse slid from one where professional judgments were acknowledged to legalism. Perhaps if the Minister's answer had been that the decisions were made by child protection experts, it would have implied that experts in the same field should have played a part in reviewing them.

This article does not contend child protection decisions should not be reviewed in different forums, including judicial ones. However the processes by which such decisions are reviewed and consideration afforded to child protection expertise are at the heart of part of a concern about the way the WA criminal record checking system is playing out.

\section{Conclusion}

In canvassing the application of the WA legislation three cases were considered. The cases became available because three individuals denied cards by the DCP appealed these decisions to the Tribunal. Initially, on review at the Tribunal each of the cases was found in favour of the appellant. Subsequently two cases were further appealed by the DCP to the Court. One of DCP's appeals was dismissed and the other remitted back to the Tribunal where eventually DCP's original decision was upheld. These three cases raise concerns about the value of cards as a child abuse prevention measure.

Other limitations to the cards effectiveness identified included: exemptions from requiring a card; WA's inability to access criminal records internationally and 
from other Australian jurisdictions; the screening not extending to the relevant records of people who do not have a criminal record; costs; duplication with the Commonwealth; and, a limited role for child protection expertise. Additionally given the lack of knowledge about the quantum of organisation located child abuse evaluating the card's impact on protecting children might never be possible. If the card engenders false security and lessened vigilance opportunities for child abuse might increase.

From these authors' perspectives in an environment where statutory child protection services are described by Bob Lonne, National President of the Australian Association of Social Workers, as "overwhelmed, legalistic and bureaucratic" (Arnold, Maio-Taddeo, Scott and Zufferey, 2008) the legislation reflects a political imperative to allay community fears by "doing something" about child abuse and the dominance of the legal discourse in child welfare. This is not unique to WA. In reflecting on legislative developments in Canada, Anglin (2002) wrote

The narrow notion of the child welfare constructed by the law ... shapes the child welfare discourses, and thus severely limits the nature of policies and services within welfare departments ... legal discourse has the dominant hand as debates take place within the courts - the domain of the law. (p. 238)

Protecting children in organisations is a complex and on-going task. Making it happen requires coordinated inputs from children, parents, administrators, staff and professionals in environments where children are valued and their interests given priority. Criminal record screening as part of proper recruitment is a supported tactic to contribute to this protection. However, it is a low order tactic because while it might remove a few dangerous people from an organisations' workforce it cannot 
effectively make organisations or their workforce safe. Those responsible for the working with children check legislation and administering it are faced with the challenge of ensuring the check does not become the dominant government authorised organisation child protection strategy. Rather, record screening needs to be understood as a relatively weak tactic contributing to organisational safety and not promoted as a quick fix to organisation-located abuse.

References

Anglin, J. (2002). Risk, well-being, and paramountcy in child protection: The need for transformation [Electronic Version]. Child and Youth Care Forum, 31, 233255. Retrieved 1 July 2007 from http://www.springerlink.com.dbgw.lis.curtin.edu.au/content/44c1ggx03vbk4ht $\underline{3 / ? \mathrm{p}=27 \mathrm{e} 6578 \mathrm{f} 0 \mathrm{~b} 00408 \mathrm{f} 93434469331230 \mathrm{aa} \& \mathrm{pi}=1}$

Arnold, L., Maio-Taddeo, C., Scott. D., \& Zufferey, C. (2008). Professionals protecting children: Child protection and social work education in Australia. Australian Centre for Child Protection, University of South Australia. 
Australian Bureau of Statistics (2006) National Regional Profile: Western Australia retrieved 18 April 2008 from the Australian Bureau of Statistics Website at http://www.abs.gov.au

Australian Institute of Health and Welfare (AIHW) 1999. Child protection Australia 1997- 98. AIHW cat. no. CWS 8. Canberra: AIHW (Child Welfare Series).

Australian Institute of Health and Welfare (AIHW) 2000. Child protection Australia 1998-99. AIHW cat. no. CWS 11. Canberra: AIHW (Child Welfare Series no. 25).

Australian Institute of Health and Welfare (AIHW) 2007. Child protection Australia 2005-06. Child welfare series no. 40. Cat. no. CWS 28. Canberra: AIHW.

Australian Institute of Health and Welfare 2008. Child protection Australia 2006-07. Child welfare series no. 43. Cat. no. CWS 31. Canberra: AIHW.

Australian Senate Community Affairs Committee. (2004). Forgotten Australians: A report on Australians who experienced institutional or out-of-home care as children. Canberra.

Bichard, M. (2004). "Birchard inquiry report." Retrieved 29 December 2008, from http://police.homeoffice.gov.uk/publications/operational-policing/bichardinquiry-report?view=Binary

Bromfield, L. M., \& Higgins, D. J. (2004). The limitations of using statutory child protection data for research into child maltreatment. Australian Social Work, 57(1), 19-30.

C and Chief Executive Office, Department for Community Development, [2007]

WASAT 116. Retrieved 20 November 2007 from http://www.austlii.edu.au/ Chief Executive Officer, Department for Child Protection-v-C, [2007] WASCA 172 retrieved 29 December 2008 from http://austlii.edu.au/ 
Chief Executive officer, Department for Child Protection v Grindrod [No 2] [2008]

WASCA 28 retrieved 28 June 2008 from http://www.austlii.edu.au/

Chief Executive Officer, Department for Child Protection-v-Scott, [2008] WASCA

171 retrieved 29 December 2008 from http://www.austlii.edu.au/

ChildWise (2008), Keeping your children safe: Choosing safe organisations and activities for your children (for Victoria). Retrieved 29 December 2008 from http://www.childwise.net/resources/online_publications.php

D and Department for Community Development, [2007] WASAT 154. Retrieved 20 November 2007 from http://www.austlii.edu.au/

Department for Child Protection. (2005). The working with children check: Working to protect our children. Retrieved 21 November 2007, from http://www.checkwwc.wa.gov.au/

Department for Child Protection. (2007). Annual Report 2006 - 2007. Retrieved 23 November 2007. from http://www.community.wa.gov.au/DCP/Publications/AnnualReports/

Department for Child Protection (2008). Annual Report 2007 - 2008. Retrieved 29 December 2008 from http://www.community.wa.gov.au/DCP/Publications/AnnualReports/ Ellery, S. (2007). Parliamentary Hansard. Page: 3194c - 3195a from http://www.parliament.wa.gov.au/web/newwebparl.nsf/iframewebpages/Hans $\underline{\operatorname{ard}+-+ \text { Advanced }+ \text { Search }}$

Father faces ban. (7 August 2007). The Sunday Times.

Gibson, D. (2007, 24 November). Staff blamed for kids' deaths. The West Australian.

Gill, T. (2007). No fear: Growing up in a risk averse society. London, Calouste Gulbenkian Foundation. 
Green, L., \& Masson, H. (2002). Adolescents Who Sexually Abuse and Residential Accommodation: Issues of Risk and Vulnerability. Br J Soc Work, 32(2), 149168.

Grindrod and Chief Executive Officer Department for Community Development,[2008] WASAT 289 retrieved on 29 December 2008 from http://austlii.edu.au/ Irenyi, M., Bromfield, L., Beyer, L., \& Higgins, D. (2006). Child maltreatment in organisations: Risk factors and strategies for prevention. Melbourne: National Child Protection ClearingHouse, Australian Institute of Family Studies.

James, M. (1996). Paedophilia. Trends and Issues in Crime and Criminal Justice Retrieved 5 August 2007, from http://www.aic.gov.au/publications/tandi/tandi57.html

McHale, S. (2004). Parliamentary Hansard [Electronic Version], page: 6945b - 6949a retrieved on 29 December 2008 from http://www.parliament.wa.gov.au/web/newwebparl.nsf/iframewebpages/Hans $\underline{\operatorname{ard}+-+ \text { Advanced+Search }}$

McHale, S. (2005) Parliamentary Hansard [Electronic Version], Page 8162b retrieved 29 December 2008 from http://www.parliament.wa.gov.au/web/newwebparl.nsf/iframewebpages/Hans $\underline{\operatorname{ard}+-+ \text { Advanced+Search }}$

Oliver, B. E. (2007). Three steps to reducing child molestation by adolescents [Electronic Version]. Child Abuse \& Neglect, In Press, Corrected Proof. Retrieved 1 November 2007 from http://www.sciencedirect.com/science/article/B6V7N-4P5RKYP3/2/543b7b9fe1b67729bf8d5825852b530d 
S and Chief Executive Officer, Department for Community Development, [2007]

WASAT 222. Retrieved 20 November 2007 from http://www.austlii.edu.au/

Sick kids. (2004, 18 June ). The West Australian.

Sylvan, K., \& Franco, L. (2008), Australian Council for Children and Youth Organisations' Safeguarding Children Program. Child Abuse Prevention Newsletter, 16, $9-13$.

Templeman, D. (2007). Parliamentary Hansard [Electronic Version], Page: 150b 151a / 1 (2007) retrieved 29 December 2008 from http://www.parliament.wa.gov.au/web/newwebparl.nsf/iframewebpages/Hans $\underline{\operatorname{ard}+-+ \text { Advanced+Search }}$

Wood, J. (1997). The Royal Commission into the New South Wales Police Service: The paedophile inquiry appendices. Retrieved 10 July 2007 from http://www.pic.nsw.gov.au/RoyalCommissionReports.aspx

Legislation

The Working with Children (Criminal Record Checking) 2004 Act (WA) retrieved on 20 October 2007 from http://www.slp.wa.gov.au State Administrative Tribunal Act 2004 (WA) retrieved on 29 December 2008 from http://www.slp.wa.gov.au 